\title{
Mixotrophy in the dinoflagellate Prorocentrum minimum
}

\author{
Diane K. Stoecker ${ }^{1, *}$, Aishao $\mathrm{Li}^{1}{ }^{1}$ D. Wayne Coats ${ }^{2}$, Daniel E. Gustafson ${ }^{1}$, \\ Michelle K. Nannen ${ }^{1}$ \\ ${ }^{1}$ University of Maryland System, Center for Environmental and Estuarine Studies, Horn Point Environmental Laboratory, \\ Cambridge, Maryland 21613, USA \\ ${ }^{2}$ Smithsonian Environmental Research Center, Box 28, Edgewater, Maryland 21037, USA
}

\begin{abstract}
Prorocentrum minimum (formerly also known as P. mariae-lebouriae) is a common bloomforming, photosynthetic dinoflagellate in Chesapeake Bay, USA. lt is also capable of ingesting other cells. In Chesapeake Bay, P. minimum usually co-occurs with cryptophytes. Ingested cryptophyte material is observable in the dinoflagellate under an epifluorescent microscope as orange-fluorescent inclusions (OFI). During April and May, the frequency of OFl was $\leq 10 \%$ in both surface and pycnocline assemblages. In summer, up to $50 \%$ of the P. minimum contained OFI. The frequency of OFI was positively correlated with cryptophyte abundance, but OFI were not frequent in all populations of $P$. minimum when cryptophyte densities were high. On-deck experimental incubations were done to determine the conditions that influence feeding. Light level and inorganic nutrient availability over the previous $24 \mathrm{~h}$ affect feeding. Incidence of feeding is lower when populations are maintained in the dark for $24 \mathrm{~h}$ than on a natural light:dark cycle. Addition of nitrate and phosphate together can inhibit feeding. Ingestion has a diel pattern, with frequency of OFI highest in the afternoon and evening and lowest in the morning. Feeding is influenced by a complex of factors, but the spatial-temporal pattern of ingestion and the experiments both suggest that feeding is primarily a mechanism for obtaining limiting inorganic nutrients rather than a mechanism for supplementing carbon nutrition during light limitation. Ingestion of other protists, including competitors for light and nutrients, may be an important strategy which allows bloom-forming dinoflagellates to dominate plankton assemblages for extended periods and during changing nutrient regimes.
\end{abstract}

KEY WORDS: Prorocentrum - Dinoflagellates · Cryptophytes - Mixotrophy · Chesapeake Bay

\section{INTRODUCTION}

Prorocentrum minimum (Pavillard) Schiller [= Prorocentrum mariae-lebouriae (Parke \& Ballintine) Faust] is a common bloom-forming dinoflagellate in temperate and subtropical waters that often persists at high densities over changing environmental conditions (Tyler \& Seliger 1978, Grzebyk \& Berland 1996). The ability of $P$. minimum to survive and grow under low light and/or nutrient stress has been a subject of several field and laboratory investigations but is not completely understood (Tyler \& Seliger 1981, Harding 1988, Harding \& Coats 1988, Sciandra 1991).

\footnotetext{
•E-mail: stoecker@hpel.cees.edu
}

In Chesapeake Bay (USA), Prorocentrum minimum undergoes subsurface transport in the spring from the southern Bay to the northern Bay, where it is upwelled and can form red tides (Tyler \& Seliger 1981). Although the bulk of the population is often below the compensation point for photosynthesis during subsurface transport, pigment content and photosynthetic capacity are maintained (Tyler \& Seliger 1978, Harding \& Coats 1988). Cells collected from the subpycnocline do not show the signs of deterioration or stress that are observed in cultures under prolonged exposure to low light (Harding \& Coats 1988).

After the initial bloom, Prorocentrum minimum populations can remain high during early summer although, in this season, prolonged periods of low light, due to turbidity, can occur in surface waters (Harding 
1988) In late summer, this dinoflagellate can maintain blooms in nutrient-poor surface waters. Nightly migrations into the pycnocline, where inorganic nutrients are more available, may explain its persistence as a dominant component of the phytoplankton during summer stratification (Tyler \& Seliger 1981)

Previous investigations of the ecology of Prorocentrum minimum have not considered the possibility that it is mixotrophic and that it might be supplementing its carbon, nitrogen or phosphorus budget through feeding. Recently, feeding has been documented in $P$. minimum and in several other bloom-forming dinoflagellates (Bockstahler \& Coats 1993b, Jacobson \& Anderson 1996, Li et al. 1996). P. minimum from the Bay often contain orange fluorescent inclusions that are primarily derived from the ingestion of phycoerythrin-containing cryptophytes (Li et al. 1996). However, the propensity to eat appears to be highly variable ( $\mathrm{Li}$ et al. 1996). Although prey density is important, olher factors appear to be important in regulating feeding by mixotrophic dinoflagellates (Bockstahler \& Coats 1993a, b). Studies of mixotrophy in non-dinoflagellate photosynthetic flagellates indicate that mixotrophy may play different roles in different taxa. In some it appears to be primarily a means of obtaining organic carbon; in others, mixotrophy is primarily a means of obtaining major inorganic nutrients (nitrogen or phosphorus) or specific growth factors (Ishida \& Kimura 1986, Sanders 1991. Caron et al. 1993, Jones et al. 1993, Nygaard \& Tobiesen 1993).

Feeding may be an important aspect of the physiological ecology of bloom-forming dinoflagellates that allows them to maintain high populations under adverse conditions or to dominate the phytoplankton for extended periods. Mixotrophy may confer competitive advantages in the phytoplankton, particularly when major nutrients are limiting (Thingstad et al. 1996). In Chesapeake Bay, the common co-occurrence of Prorocentrum minimum with phycoerythrin-containing cryptophyte prey provides a convenient system in which to examine the factors that cause this photosynthetic dinoflagellate to ingest prey. Field samples were collected and on-deck experimental incubations done to test the following hypotheses: (1) Feeding occurs during subpycnocline transport (light-limiting conditions) and is primarily a mechanism for supplementing carbon nutrition. (2) Feeding occurs when major inorganic nutrients are limiting and is primarily a mechanism for obtaining nitrogen and/or phosphorus.

\section{METHODS}

Field sampling. In order to describe and analyse the temporal and spatial pattern of ingestion of crypto- phytes by Prorocentrum minimum, samples were taken from the surface and the fluorescence maximum in the pycnocline at routine stations along the mainstem of Chesapeake Bay during July and August 1995 and monthly between April and September 1996 (Fig. 1). CTD (conductivity, temperature, depth, plus fluorescence) Niskin bottle casts were made during daylight to profile the water column. Duplicate sam-

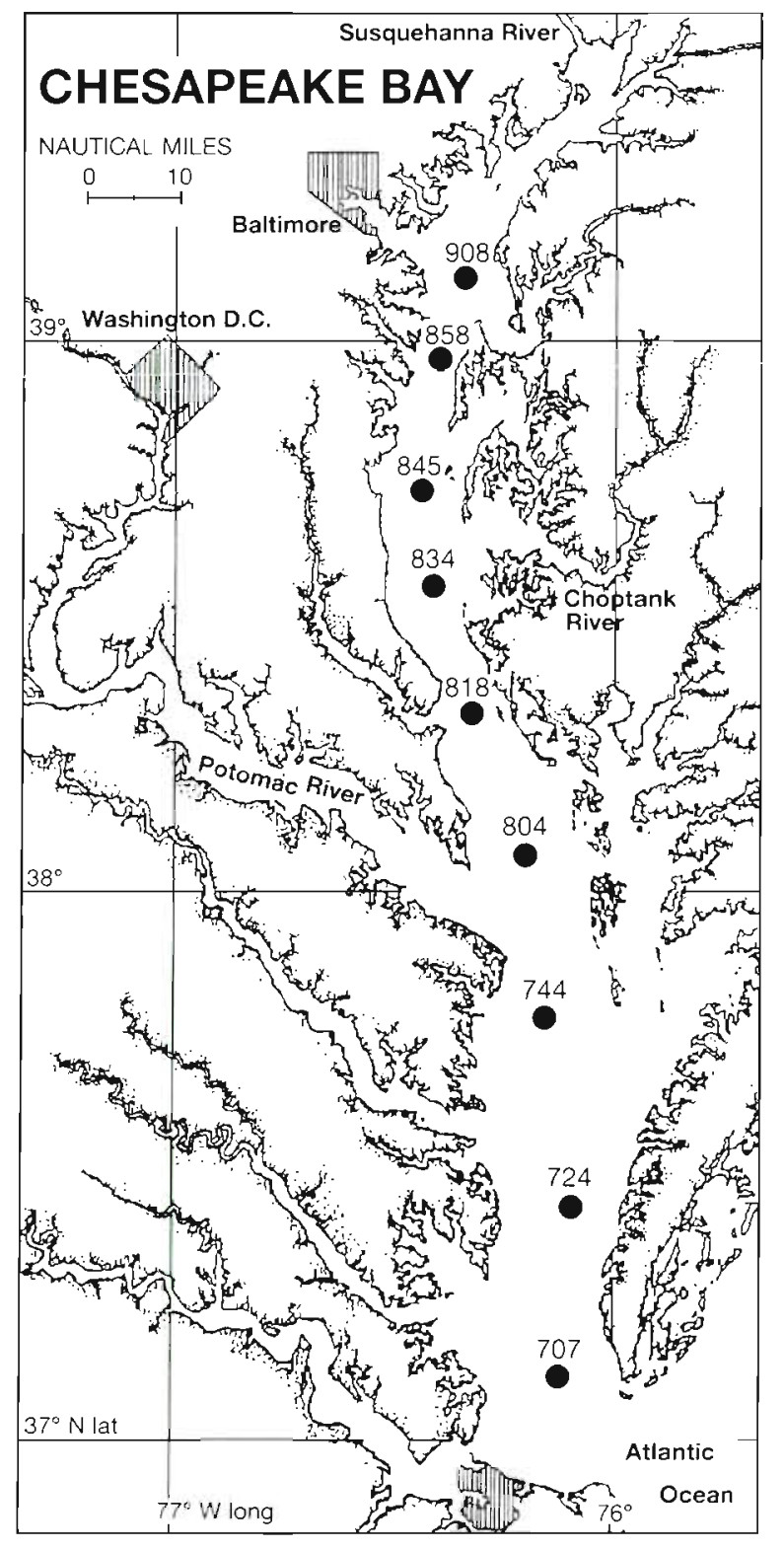

Fig. 1. Chesapeake Bay showing locations of routine stations in 1995 and 1996. Station positions from north to south are: $908\left(39^{\circ} 08^{\prime} \mathrm{N}, 76^{\circ} 20^{\prime} \mathrm{W}\right) ; 858\left(38^{\circ} 58^{\prime} \mathrm{N}, 76^{\circ} 23^{\prime} \mathrm{W}\right) ; 845$ $\left(38^{\circ} 45^{\prime} \mathrm{N}, 76^{\circ} 26^{\prime} \mathrm{W}\right): 834\left(38^{\circ} 34^{\prime} \mathrm{N}, 76^{\circ} 26^{\prime} \mathrm{W}\right) ; 818\left(38^{\circ} 18^{\prime} \mathrm{N}\right.$, $\left.76^{\circ} 17^{\prime} \mathrm{W}\right) ; 804\left(38^{\circ} 04^{\prime} \mathrm{N}, 76^{\circ} 13^{\prime} \mathrm{W}\right) ; 744\left(37^{\circ} 44^{\prime} \mathrm{N}, 76^{\circ} 11^{\prime} \mathrm{W}\right)$; $724\left(37^{\circ} 24^{\prime} \mathrm{N}, 76^{\circ} 05^{\prime} \mathrm{W}\right) ; 707^{\prime}\left(37^{\circ} 07^{\prime} \mathrm{N}, 76^{\circ} 07^{\prime} \mathrm{W}\right)$. Stations from north to south are $248,238,212,189,156,127,86,44$, and $9 \mathrm{~km}$ from the mouth of the Bay 
ples for inorganic nutrient analyses (nitrate, nitrite, ammonia and dissolved inorganic phosphate) were gently filtered through GF/F filters and stored frozen $\left(-20^{\circ} \mathrm{C}\right)$ in acid-washed scintillation vials until analysis (Technicon Autoanalyzer II, Bran and Luebbe detector, TAOS software).

For microscopic analyses, whole water samples $(20 \mathrm{ml})$ were immediately fixed in $1 \%$ (final conc.) glutaraldehyde and stored at $4{ }^{\circ} \mathrm{C}$ until 10 to $20 \mathrm{ml}$ subsamples were filtered onto $2 \mu \mathrm{m}$ pore black membrane filters (Poretics Corporation). Filters were mounted on glass slides with immersion oil (Resolve) and capped with a coverslip. Slides were stored frozen at $-20^{\circ} \mathrm{C}$ and were subsequently examined with epifluorescence microscopy (Zeiss filter set 487709; BP450-490 exciter filter, FT 510 dichromatic beam splitter, and LP520 barrier filter). Prorocentrum minimum and orange-fluorescent cryptophytes were enumerated at $400 \times$. One hundred $P$. minimum were routinely scored for the presence or absence of orange fluorescent inclusions (OFI) on each filter.

Experimental incubations with natural assemblages. Surface assemblages, containing $\geq 50$ Prorocentrum minimum $\mathrm{ml}^{-1}$ and in which OFI were present, were used in the experimental incubations. Acid-washed polycarbonate carboys or bottles were used aboard the RV 'Cape Henlopen' for the on-deck incubations in flowing sea-water tables which maintained close to in situ surface water temperatures. Neutral density screening was used to obtain irradiances of ca $64 \%$ incident, unless otherwise noted. In prey addition experiments and feeding trials, cultured Cryptomonas sp. (clone g) grown in $\mathrm{f} / 2$ medium without silicate (Guillard 1975) prepared from filtered Choptank River water (10 to 15 psu) was added. Procedures for enumeration of $P$. minimum, cryptophytes and for determination of OFI were similar to those used for field sampling, except that 200 to 300 cells were scored for the presence of OFI.

Two preliminary experiments were performed to determine the time course of response of Prorocentrum minimum to addition of prey and/or major inorganic nutrients. The first preliminary experiment was done with a surface sample $\left(9.3 \mathrm{psu}, 26^{\circ} \mathrm{C}\right)$ collected from the mouth of the Potomac River $\left(38^{\circ} 00^{\prime} \mathrm{N}, 76^{\circ} 19^{\prime} \mathrm{W}\right)$ on 9 July 1995. Two $500 \mathrm{ml}$ bottles were each filled with $300 \mathrm{ml}$ surface water and then $5 \mathrm{ml}$ of cryptophyte culture was added to 1 bottle. The bottles were incubated on deck for $17 \mathrm{~h}$, with $20 \mathrm{ml}$ subsamples removed and fixed at 2 to 3 h intervals.

A second preliminary experiment was done the next day with surface water $\left(14.6 \mathrm{psu}, 26^{\circ} \mathrm{C}\right)$ collected at $38^{\circ} 13^{\prime} \mathrm{N}, 76^{\circ} 21^{\prime} \mathrm{W}$. The experimental design was similar to the first experiment, except that a third treatment was added, a control for the addition of nutrients with the addition of cultured prey. The treatments were: control (no addition), addition of cultured Cryptomonas sp. $(20 \mathrm{ml})$, and addition of an equivalent amount of medium ( $20 \mathrm{ml}$ of $\mathrm{f} / 2-\mathrm{Si}$ to $300 \mathrm{ml}$ of sample).

Based on the results of these preliminary experiments, a time course experiment was designed to document diel feeding patterns and to examine the effect of inorganic nutrient addition $1+88 \mathrm{M}$ nitrate +3.6 M phosphate) on feeding. At 11:00 h on 2 June 1996, surface water containing $\sim 150$ Prorocentrum minimum $\mathrm{ml}^{-1}$ was collected at Stn 724 and dispensed into two $10 \mathrm{l}$ carboys. To the control carboy, nothing was added. To the second carboy, $1 \mathrm{ml}$ of $\mathrm{f} / 2$ nitrate and $1 \mathrm{ml}$ of $\mathrm{f} / 2$ phosphate stock solution was added. A series of feeding trials was done with water from each carboy. For each trial, triplicate $100 \mathrm{ml}$ subsamples were removed from the carboys, $5 \mathrm{ml}$ of the cryptophyte culture added to each subsample (final density $\sim 1 \times 10^{4}$ cryptophytes $\mathrm{ml}^{-1}$ ), and the subsamples were incubated for $3 \mathrm{~h}$ in the on-deck incubator and then preserved with glutaraldehyde. New feeding trials were set up every $3 \mathrm{~h}$, with the final incubation ending on 3 June at 17:00 h.

On 16 August 1996, another nutrient addition experiment was done to determine if nutrient ratios were important. Surface water containing Prorocentrum minimum was collected at $37^{\circ} 50^{\prime} \mathrm{N}, 76^{\circ} 04^{\prime} \mathrm{W}(11.9 \mathrm{psu}$, $26^{\circ} \mathrm{C}$ ) The treatments were set up at 14:00 h, when triplicate $250 \mathrm{ml}$ bottles were filled with aliquots of the water. The controls were unamended, $883 \mathrm{M}$ nitrate was added to the $+\mathrm{N}$ replicates, $36 \mathrm{M}$ phosphate was added to the $+\mathrm{P}$ replicates, and both nutrients were added to the $+N+P$ replicates. After $24 \mathrm{~h}$ incubation, cultured Cryptomonas sp. was added to each bottle to achieve densities of $2 \times 10^{3} \mathrm{ml}^{-1}$ and the bottles were incubated for another $2 \mathrm{~h}$, after which the contents were preserved.

An experiment was carried out to determine the effect of light level on feeding by Prorocentrum minimum. On 7 July 1996, a surface sample was obtained at $37^{\circ} 47^{\prime} \mathrm{N}, 76^{\circ} 00^{\prime} \mathrm{W}$ with $-100 \mathrm{P}$. minimum cells $\mathrm{ml}^{-1}$. Eighteen $250 \mathrm{ml}$ bottles were filled at 13:00 h. Triplicate bottles were incubated on-deck without added screening $\left(100 \% I_{0}\right)$, with $1\left(\sim 50 \% I_{0}\right), 2\left(-25 \% I_{0}\right)$, $3\left(\sim 13 \% I_{0}\right)$, and 4 layers of screening $\left(\sim 6 \% I_{0}\right)$ or wrapped with aluminum foil and tape (dark treatment). After $24 \mathrm{~h}, 5 \mathrm{ml}$ of Cryptomonas sp. culture was added to each replicate to achieve densities of $\sim 2 \times$ $10^{3}$ cells $\mathrm{ml}^{-1}$. The bottles were incubated for another $2 \mathrm{~h}$ and then the contents preserved.

Experimental incubations with cultured Prorocentrum minimum. In the spring of 1995, P. minimum was isolated from a Chesapeake Bay sample and subsequently maintained in the laboratory in $\mathrm{f} / 2-\mathrm{Si}$ medium prepared from Choptank River water (15 psu) 
and exposed to a $12 \mathrm{~h}: 12 \mathrm{~h}$ light:dark cycle at $20^{\circ} \mathrm{C}$ and $\sim 150 \mu \mathrm{E} \mathrm{m} \mathrm{m}^{-2} \mathrm{~s}^{-1}$ Prior to the September 1995 cruise, duplicate 2.5 l cultures of $P$. minimum were grown for 1 wk in either $\mathrm{f} / 2-\mathrm{Si}$ or in medium with only the trace metal chelator $f / 2$ stock added (TM medium). The experimental cultures were then transferred to the on-deck incubator and held at $\sim 25 \% I_{0}$ and ambient surface water temperatures. The following day the first feeding experiment began. From each duplicate, a $300 \mathrm{ml}$ subsample was taken at 11:00 $\mathrm{h}$ and incubated on deck with $6 \mathrm{ml}$ of added cryptophyte culture $\left(\sim 3 \times 10^{3}\right.$ cryptophytes $\left.\mathrm{l}^{-1}\right)$ for $31 \mathrm{~h}$, with subsamples taken and preserved after $3 \mathrm{~h}$ and every 4 h thereafter

On the same day at 19:30 h, a second experiment was initiated with the culture grown in the TM medium. Duplicate experimental bottles, each containing $300 \mathrm{ml}$ of the TM culture, were set up without any addition (controll and with the addition of $\mathrm{f} / 2$ levels of nitrate $(883 \mu \mathrm{M})$ and phosphate $(36 \mu \mathrm{M})$. The next day at 09:00 h (approx. 13.5 h after the nutrient addition to 1 treatment), $6 \mathrm{ml}$ of cryptophyte culture was added to each bottle to achieve $\sim 3 \times 10^{3}$ cryptophytes $\mathrm{ml}^{-1}$, and the bottles were incubated on deck with subsamples taken and fixed after 2, 4,6 and $9 \mathrm{~h}$

Statistical analyses. All statistical analyses were done with SigmaStat Version 2.0 (Jandel Scientific software). An arcsin square root transformation was routinely applied to frequency data. Parametric tests were used unless data failed tests for homogeneity of variance and normality; in these cases, non-parametric tests were used.

\section{RESULTS}

\section{Spatial and temporal distributions}

Prorocentrum minimum and orange-fluorescent cryptophytes were found in Chesapeake Bay during cruises in 1995 and 1996 (Figs. 2 to 4) Frequency of OFI, which indicate ingestion of cryptophytes, is presented for samples in which $\geq 100 P$. minimum cells were scored. In June 1995, P. minimum densities in the surface and pycnocline were $\leq 4 \mathrm{ml}^{-1}$ except at Stn 744 . where densities at the surface were 41 cells $\mathrm{ml}^{-1}$ and approximately $11 \%$ of the cells had OFI (data not shown). By the July cruise, $P$ minimum density in surface waters at Stn 818 were 284 cells $\mathrm{ml}^{-1}$, with lower densities to the north and south (Fig, 2). Surface and pycnocline densities of $P$. minimum were usually similar, except at Stn 818, where surface densities were an order of magnitude higher than in the pycnocline. The frequency of OFI was highest at stations on the northern (Stn 845) edge of the bloom, although crypto- phyte densities were $>1000 \mathrm{ml}^{-1}$ in surface waters at most stations (Fig. 2). By the August cruise, pycnocline densities of $P$. minimum were low and surface populations were only $>100$ cells $\mathrm{ml}^{-1}$ at one station (Fig. 2). During this cruise cryptophyte densities were also low and frequency of OFI was $<5 \%$ (Fig. 2).

In spring 1996, Prorocentrum minimum populations did not reach 100 cells $\mathrm{ml}^{-1}$ in surface waters until

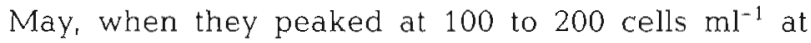
Stn 818 (Fig. 3). Frequency of OFI reached over 10\% in surface waters in both April and May (Fig. 3). During the July cruise surface populations of $P$. minimum were $>1000$ cells $\mathrm{ml}^{-1}$ in the mid-Bay; however frequency of OFI was generally low at these stations although cryptophytes were abundant (Fig. 3). Frequency of OFI was high, $>20 \%$, in surface and pycnocline populations closer to the mouth of the Bay, where $P$. minimum densities were $<500$ cells $\mathrm{ml}^{-1}$ (Fig. 3 ). By the July and August 1996 cruises, P. minimum densities were $<100$ cells $\mathrm{ml}^{-1}$ in surface waters (Fig, 4) and $<10 \mathrm{ml}^{-1}$ in the pycnocline (data not shown). During July, frequency of OFI was $>20 \%$ at Stns 848 , 834 and 804, which corresponded to the population peaks (Fig. 4). By August, frequency of OFI was very low (Fig. 4).

In 1995 and 1996 combined, 66 samples were collected in which Prorocentrum minimum was abundant enough for calculation of frequency of OFI. Of these, data on inorganic nutrient concentrations were obtained for 51 samples (Table 1). Frequency of OFI was positively associated with cryptophyte abundance and ammonia concentration, but correlations with the other variables were not statistically significant (Table 1). For 23 station/sampling date combinations, data on frequency of OFI were available for both the surface and pycnocline. There was no significant difference between the median frequency of OFI in the surface $(4 \%)$ and in the pycnocline (2\%) (Wilcoxon Signed Rank Test, $p=0.274$ ).

\section{On-deck experimental incubations}

In the 9 July 1995 preliminary experiment, the cryptophyte density was $2.0 \times 10^{3}$ cells $\mathrm{ml}^{-1}$ in the control, and $4.4 \times 10^{3}$ cells $\mathrm{ml}^{-1}$ in the treatment with added Cryptomonas sp. at the beginning of the incubation. At the end of the incubation, cryptophyte densities were $0.9 \times 10^{3}$ and $4.1 \times 10^{3}$ cells $\mathrm{ml}^{-1}$ in the control and treatment, respectively. In the 10 July 1995 preliminary experiment, the intial cryptophyte density was $1.6 \times 10^{3}$ cells $\mathrm{ml}^{-1}$ in the control and the treatment with added medium and $7.7 \times 10^{3}$ cells $\mathrm{ml}^{-1}$ in the treatment with added Cryptomonas sp. At the end of the incubation, the average cryptophyte densities in the 
July 1995
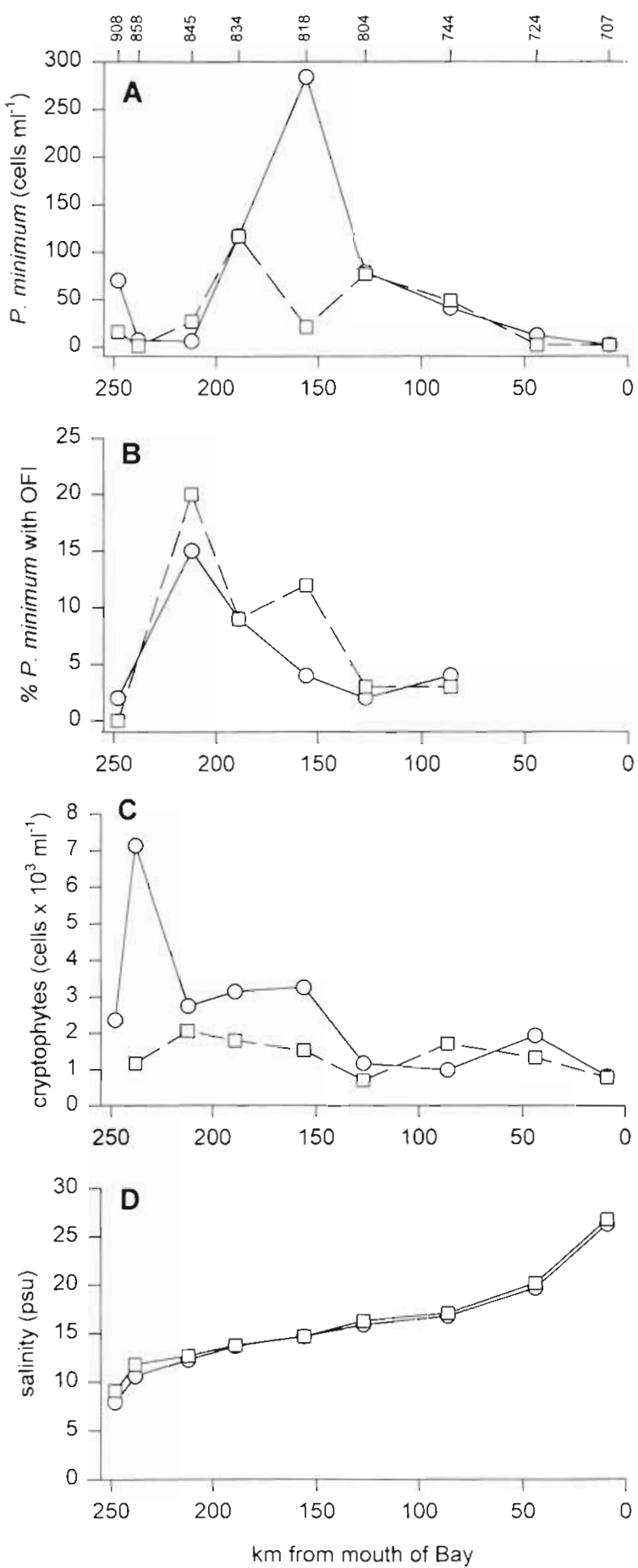

August 1995
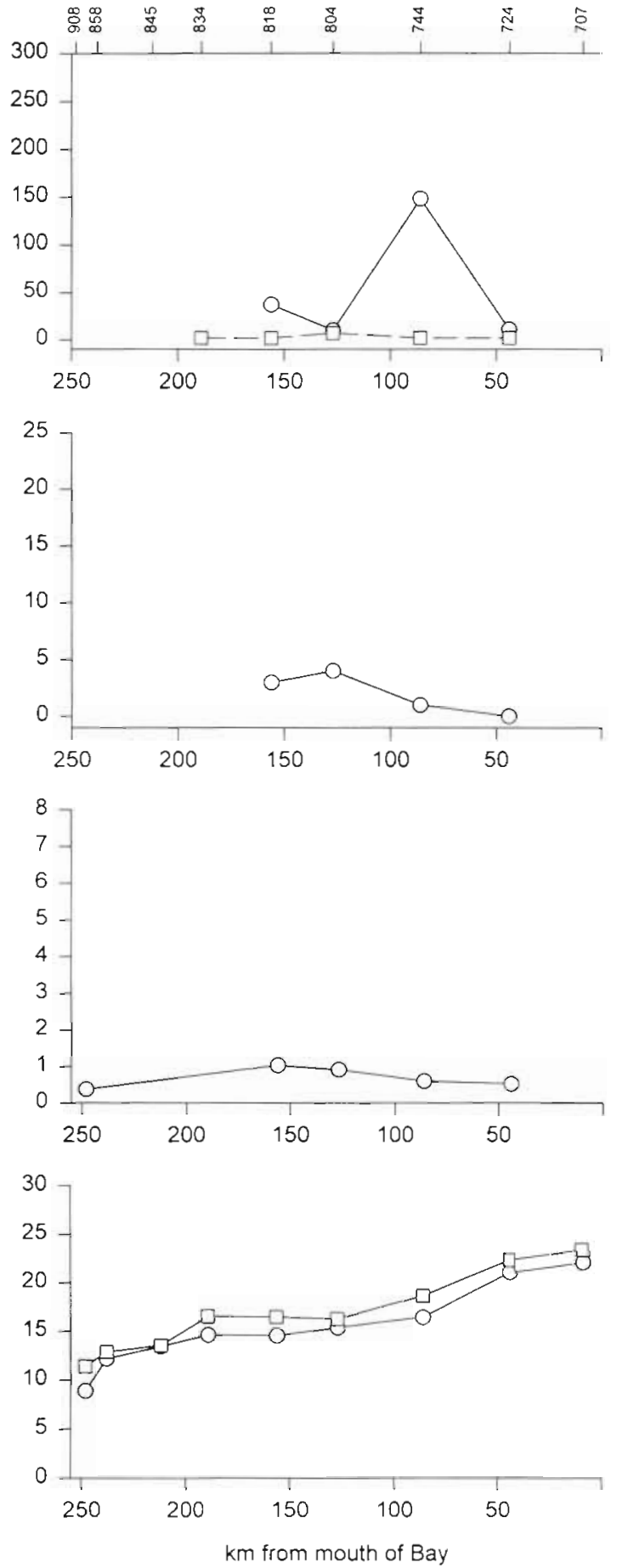

Fig. 2. (A) Abundance of Prorocentrum minimum, (B) percent of $P$. minimum with orange fluorescent inclusions (OFI), (C) abundance of cryptophytes and (D) salinity at the surface (O) and pycnocline $(\square)$ at routine stations along the mainstem of Chesapeake Bay, July and August 1995. Station numbers are given at the top of the panels

control, added prey, and added inorganic nutrient treatments were $0.1 \times 10^{3}, 5.0 \times 10^{3}$ and $1.9 \times 10^{3}$ cells $\mathrm{ml}^{-1}$, respectively. In both preliminary experiments, the diel cycle appeared to have a pronounced influence on feeding, with percent OFI high in the late afternoon and evening, decreasing in the late evening, low in the morning and then increasing dramatically again in the afternoon (Fig. 5). 
April 1996
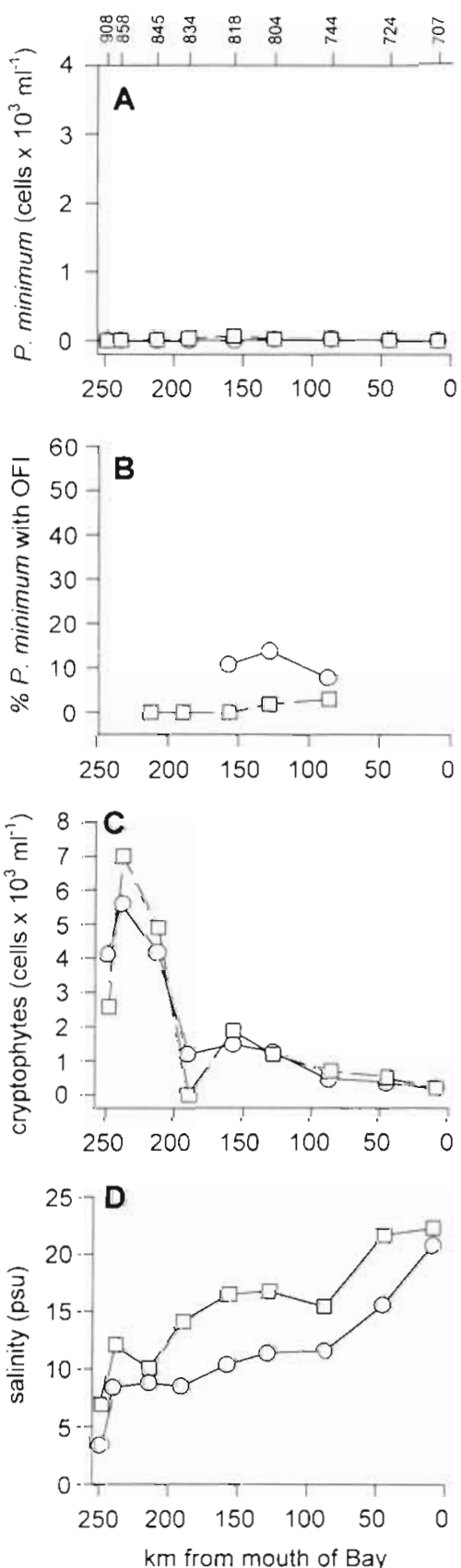

May 1996

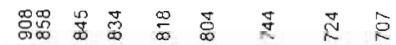
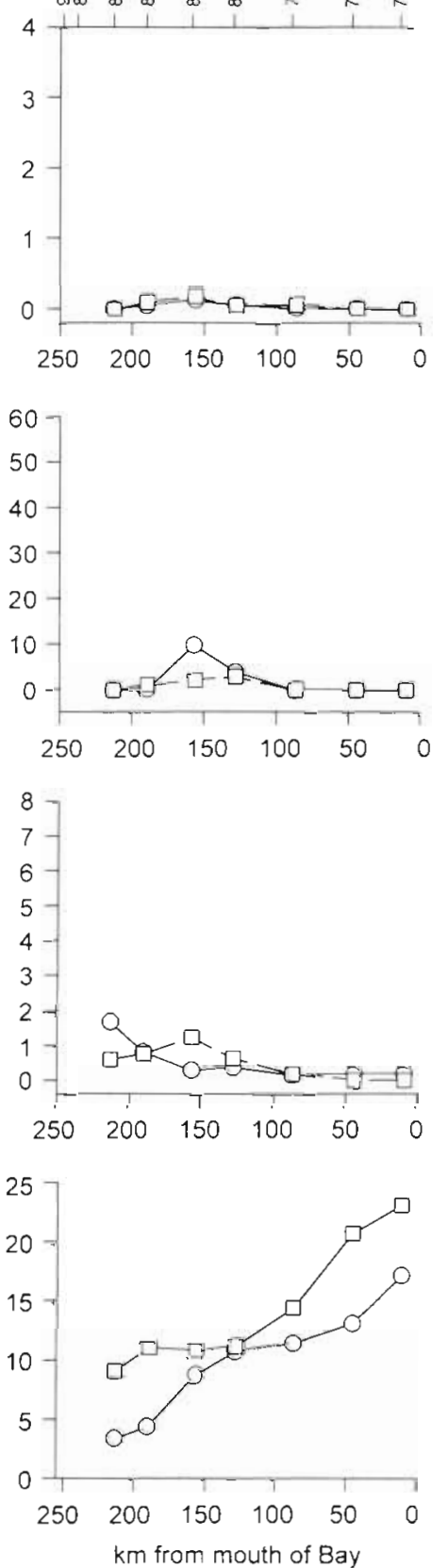

June 1996
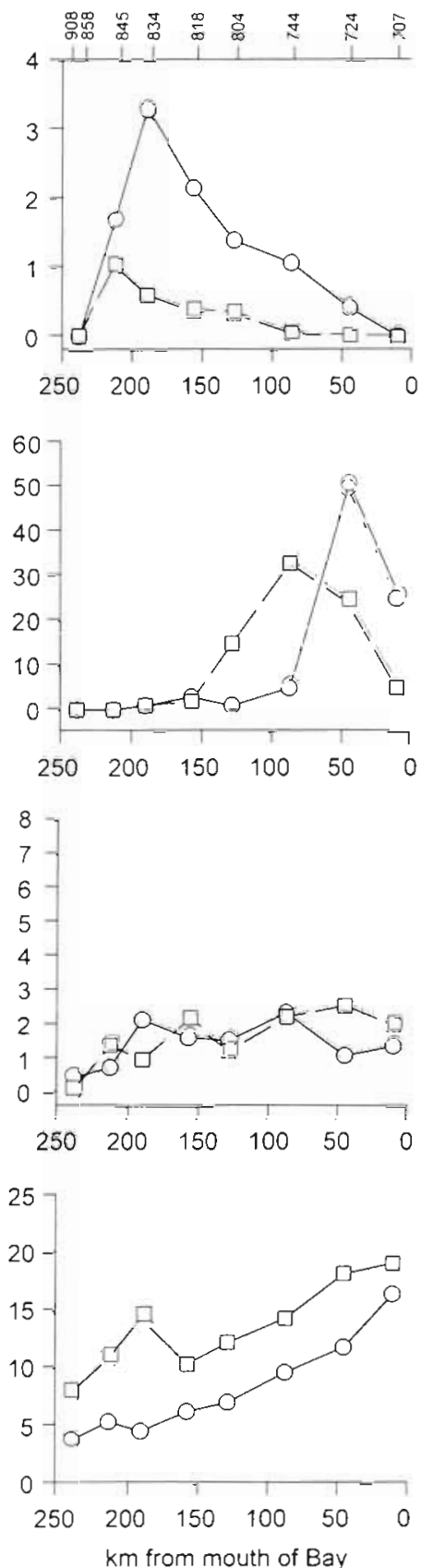

Fig. 3. (A) Abundance of Prorocentrum minimum, (B) percent of $P$. minimum with orange fluorescent inclusions (OFI). (C) abundance of cryptophytes and (D) salinity at the surface (O) and pycnocline $(\square)$ at routine stations along the mainstem of Chesapeake Bay, spring 1996. Station numbers are given at the top of the panels

Based on the preliminary experiments, a replicated time course experiment was designed to document the diel pattern in feeding, with and without nutrient addition $(+88 \mu \mathrm{M}$ nitrate and $+3.6 \mu \mathrm{M}$ phosphate; ambient concentrations were $-32 \mu \mathrm{M}$ dissolved inorganic nitrogen and $0.06 \mu \mathrm{M}$ dissolved inorganic phosphate). Nutrient addition had no significant effect on feeding $(p=0.1749)$ but time of day had a significant effect $(p<$ 0.0001 ) (2-way ANOVA). Feeding at night (23:00, 02:00, and 05:00 h) was higher than the during the previous afternoon (14:00 and 17:00 h) and the next day (08:00 to 17:00 h) (Student-Newman-Keuls method for pairwise multiple comparisons, $p<0.05$ except for comparison of $14: 00$ and 23:00 h). In both the control 

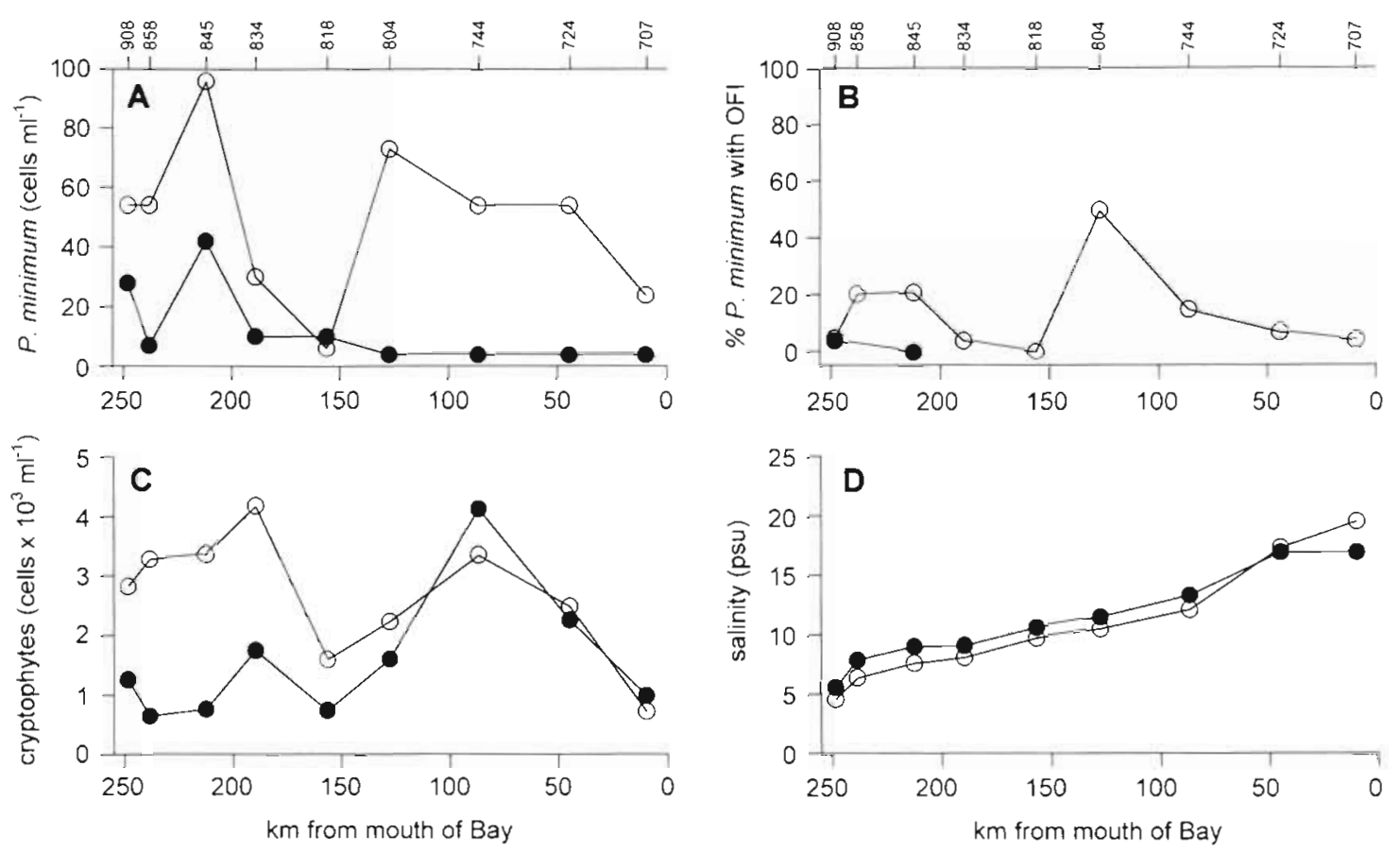

Fig. 4. (A) Abundance of Prorocentrum minimum, (B) percent of P. minimum with orange fluorescent inclusions (OFI), (C) abundance of cryptophytes and (D) salinity in surface waters at routine stations along the mainstem of Chesapeake Bay during July (O) and August ( 1996 . Station numbers are given at the top of the panels

and nutrient addition treatments, feeding increased in the afternoon, was high in the evening, and decreased drastically in the early morning (Fig. 6), the same pattern as seen in the preliminary experiments (Fig. 5).

During 1996, another nutrient addition experiment was done with a natural assemblage (Fig. 7), but using higher concentrations of added nutrients $1+36 \mu \mathrm{M}$ phosphate, $+883 \mu \mathrm{M}$ nitrate, or both) than in the previous experiment. In this second experiment, the replicate bottles were exposed to the nutrient treatments for $24 \mathrm{~h}$ prior to an afternoon feeding trial. The nutrient additions had a significant effect on percentage of OFI

Table 1. Prorocentrum minimum. Correlation of frequency of orange-fluorescent inclusions (OFI) with sampling, physicalchemical and biological parameters. Pearson Product Moment correlation with an arcsin transformation of frequency of OFI. $p<0.05$

\begin{tabular}{|lrcc|}
\hline Parameter & Coefficient & p-value & $\begin{array}{c}\text { No. of } \\
\text { samples }\end{array}$ \\
\hline Time of day $(\mathrm{h})$ & -0.174 & 0.162 & 66 \\
Depth $(\mathrm{m})$ & -0.193 & 0.120 & 66 \\
Temperature $\left({ }^{\circ} \mathrm{C}\right)$ & 0.192 & 0.122 & 66 \\
Salinity $(\mathrm{psu})$ & 0.062 & 0.622 & 66 \\
$\mathrm{NO}_{2}+\mathrm{NO}_{3}(\mu \mathrm{M})$ & -0.208 & 0.142 & 51 \\
$\mathrm{NH}_{4}(\mu \mathrm{M})$ & 0.321 & 0.022 & 51 \\
$\mathrm{PO}_{4}(\mu \mathrm{M})$ & -0.041 & 0.777 & 51 \\
$P_{\text {. minimum }\left(\text { cells } \mathrm{ml}^{-1}\right)}$ & -0.122 & 0.330 & 66 \\
Cryptophytes (cells ml $\left.{ }^{-1}\right)$ & 0.307 & 0.012 & 66 \\
\hline
\end{tabular}

(1-way ANOVA with arcsin square root transformation, $\mathrm{p}=0.0137$ ). Feeding was significantly higher in the $+\mathrm{N}$ treatment than in the $+\mathrm{N}+\mathrm{P}$ treatment $(\mathrm{p}<$ $0.05)$. All other pairwise comparisons were not significant $(\mathrm{p}>0.05)$. Addition of both inorganic nutrients in combination prevented feeding (Fig. 7).

In on-deck experiments with cultured Prorocentrum minimum, feeding was only observed in the cultures which had been grown to stationary phase in the low nutrient (TM) medium (Fig. 8A). The median percent of OFI in cultures grown in the TM medium was significantly higher than in cultures grown in complete medium (Mann-Whitney Rank Sum test, $p<0.0001$ ). Percent OFI decreased with time in the TM group (Kruskal-Wallis 1-way ANOVA on ranks, $p=0.0474$ ). Within $24 \mathrm{~h}$, addition of inorganic nitrate and phosphate to the cultures grown in the low nutrient medium inhibited feeding (Fig. 8B). There was a statistically significant difference in the median percent of OFl between the amended and control treatment groups (Mann-Whitney Rank Sum test, $p=0.0002$ ).

In order to determine whether history of light exposure influences the propensity to eat, feeding trials were done with Prorocentrum minimum in a natural assemblage which had been exposed for $24 \mathrm{~h}$ to either darkness or screened to produce a range of light levels in an on-deck incubator (Fig. 9). Light level had a significant effect on abundance of $P$. minimum (1-way ANOVA, $p=0.0020)$, probably due to 


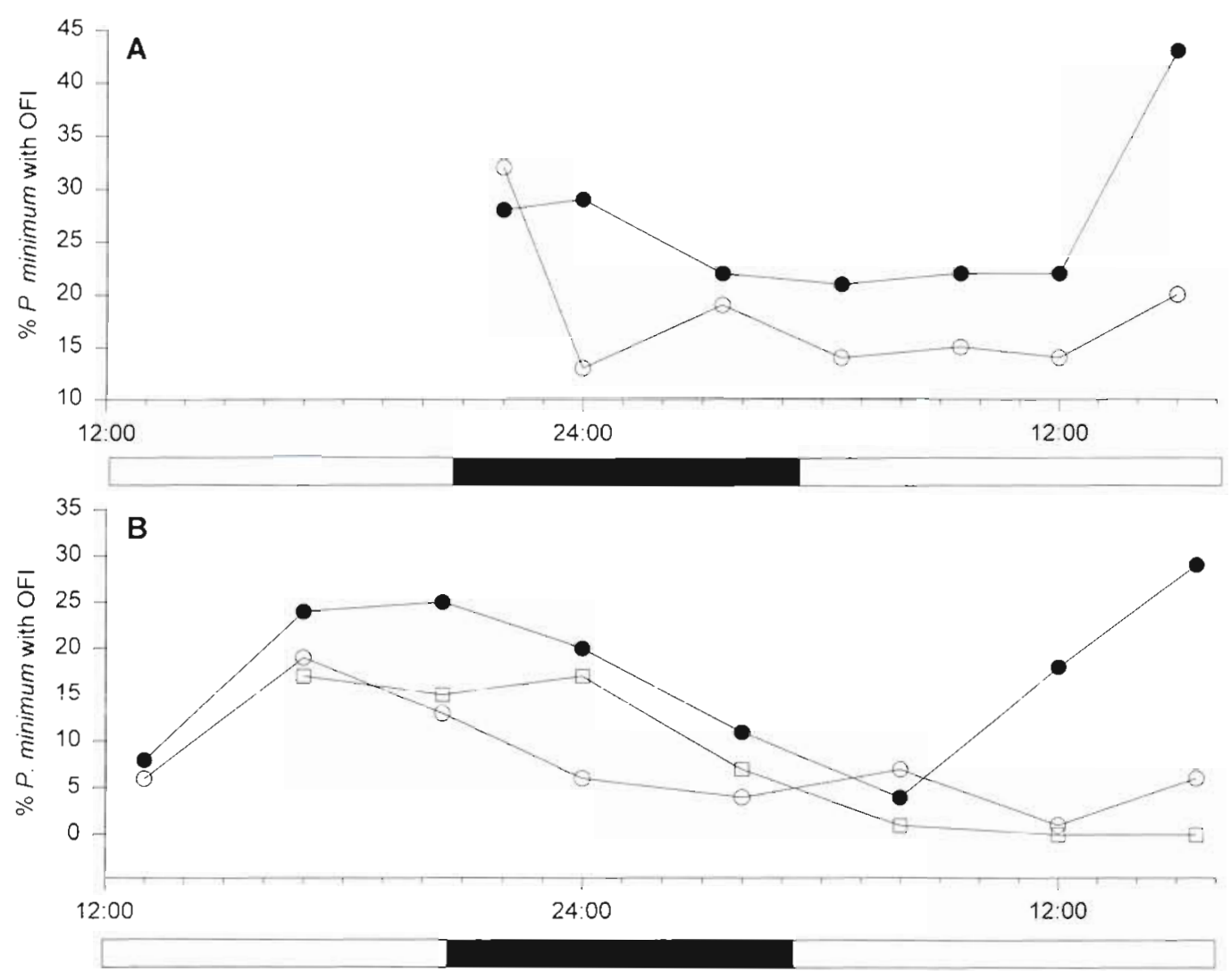

Fig. 5. Prorocentrum minimum. Effects of manipulation of prey density, inorganic nutrient availability and time of day on percent of cells with orange fluorescent inclusion (OFI) in on-deck experiments with natural assemblages. Black bar indicates interval between sunset and sunrise. (A) 9 July 1995 experiment, (B) 10 July 1995 experiment. (O) Controls; (O) added cryptophytes,

(ㅁ) added medium treatment

lack of growth in the dark. After $24 \mathrm{~h}$, abundance in the dark was significantly lower than at $100 \% I_{0}(p<$ 0.05). Light level also had a significant effect on feeding (1-way ANOVA, $p=0.0013)$. Frequency of OFI was significantly higher $(p<0.05)$ in all light treatments than in the dark. One-day exposure to between 6 and $100 \%$ incident irradiance did not affect feeding, but being kept in the dark resulted both in lower P. minimum density and a reduction in feeding.

\section{DISCUSSION}

Prorocentrum spp. are photosynthetic and heavily armoured, and thus they were considered to be strictly autotrophic by most phytoplankton ecologists. However, some species are able to ingest prey through a feeding tube. Tube feeding is common among both non-thecate and thecate dinoflagellates and allows feeding to occur through a narrow opening (reviewed in Schnepf \& Elbrächter 1992). In myzocytotic feeding, the tip of the feeding tube penetrates the plasma membrane of the host or prey cell without rupturing it. The contents of the prey cell are plasmolysed and are transported through the tube to the parasite or predator. Whole organelles may be transported up the feeding tube and encorporated into food vacuoles in the predator. When the feeding tube is not extended, it is described as a microtubular basket. Schnepf \& Winter (1990) observed a microtubular basket in Prorocentrum micans and surmised that this species is capable of myzocytosis. They interpreted similar structures observed by Faust (1974) in Prorocentrum minimum (as P. mariae-lebouriae) as microtubular baskets. The presence of food vacuoles has recently been confirmed in both of these species (Jacobson \& Anderson 1996, Li et al. 1996). In P. minimum ingested phycoerythrincontaining prey appear as small $(\leq 5 \mu \mathrm{m})$ spherical, orange fluorescent inclusions (Fig. 1C in Li et al. 1996), which is consistent with a tube feeding mechanism in which prey organelles are transported through the feeding tube to the predator's cell body and then incorporated into food vacuoles.

We hypothesized that Prorocentrum minimum uses feeding to supplement its carbon budget during subsurface transport under light-limiting conditions. How- 


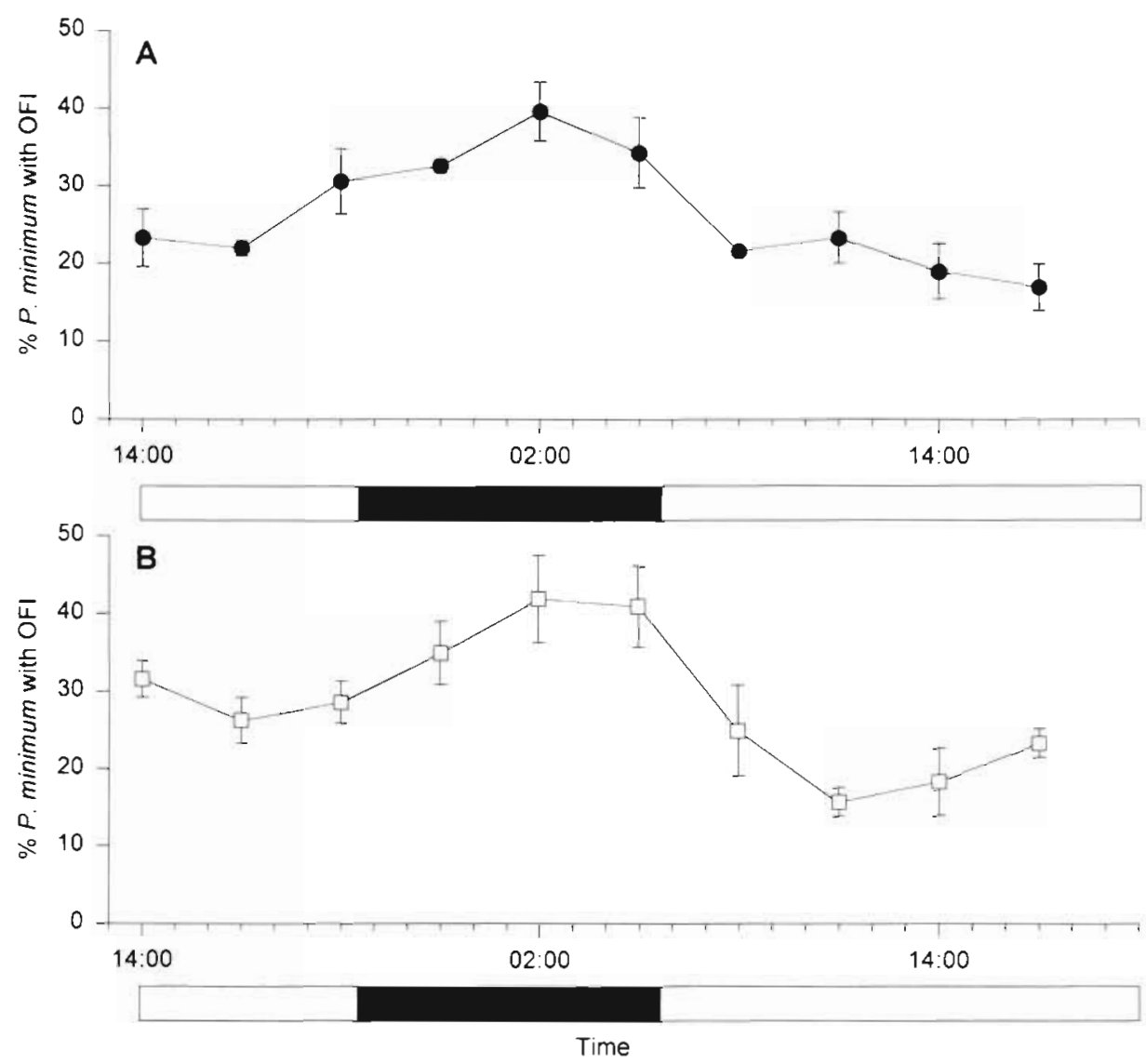

Fig. 6. Prorocentrum minimum. Effect of time of day on percent of cells with orange fluorescent inclusions (OFI), 2 to 3 June 1996 on-deck experiment with natural assemblages. Black bar indicates interval between sunset and sunrise. Mean \pm SE for feeding trials with water from $(\mathrm{A})$ control treatment (no nutrient addition) and (B) treatment with addition of $88 \mu \mathrm{M}$ nitrate and $3.6 \mu \mathrm{M}$ phosphate

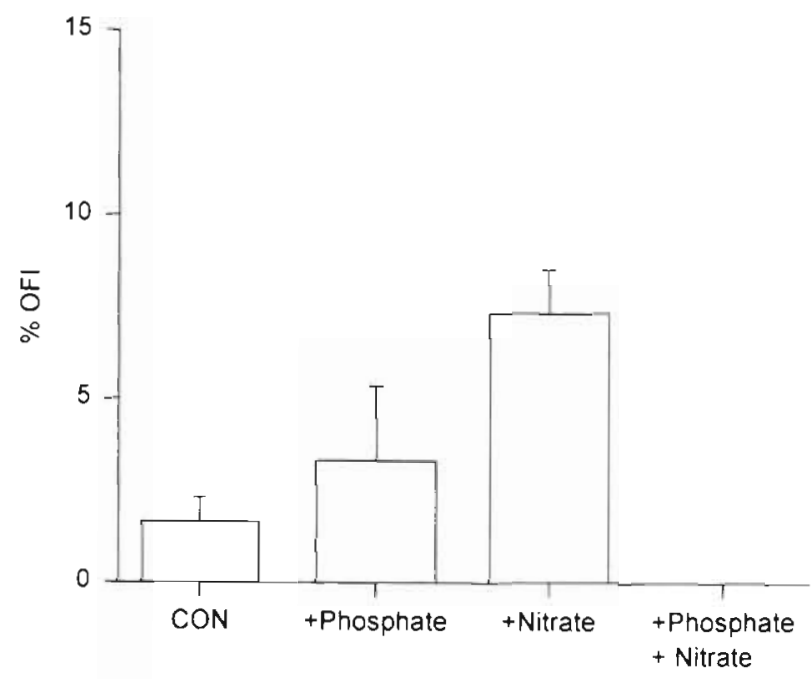

Fig. 7. Prorocentrum minimum. Effect of addition of inorganic nutrients on feeding by cells from natural assemblages, 16 August 1996. $+\mathrm{P}$ : addition of $36 \mu \mathrm{M}$ phosphate, $+\mathrm{N}$ : addition of $883 \mu \mathrm{M}$ nitrate, $+\mathrm{N}+\mathrm{P}$ : addition of $36 \mu \mathrm{M}$ phosphate and $883 \mu \mathrm{M}$ nitrate. Presence of orange fluorescent inclusions (OFI) indicates feeding on cryptophytes. Mean $\pm S E$ ever, both the field observations and on-deck experimental incubations indicate that feeding in $P$. minimum is not a response to light limitation. Incidence of OFI in pycnocline populations was no higher than in surface populations. Prolonged ( $24 \mathrm{~h}$ ) incubation in the dark decreases, rather than increases, feeding. Mixotrophy does not appear to be a mechanism for this species to supplement its carbon nutrition or to survive and grow under light-limiting conditions during subsurface transport.

It appears more likely that feeding in Prorocentrum minimum is a response to inorganic nutrient depletion and/or a mechanism for obtaining trace growth factors. Feeding was most common during summer, when phytoplankton growth rates in the Bay appear to be limited by dissolved inorganic nitrogen (Malone et al. 1996). The on-deck experiments support the hypothesis that inorganic nutrient limitation induces feeding in $P$. minimum. Within $24 \mathrm{~h}$, addition of high concentrations of nitrate $(883 \mu \mathrm{M})$ and phospshate $(36 \mu \mathrm{M})$ inhibited feeding in experiments with natural assemblages (Fig. 7) and with cultures (Fig. 8). In the experiments 

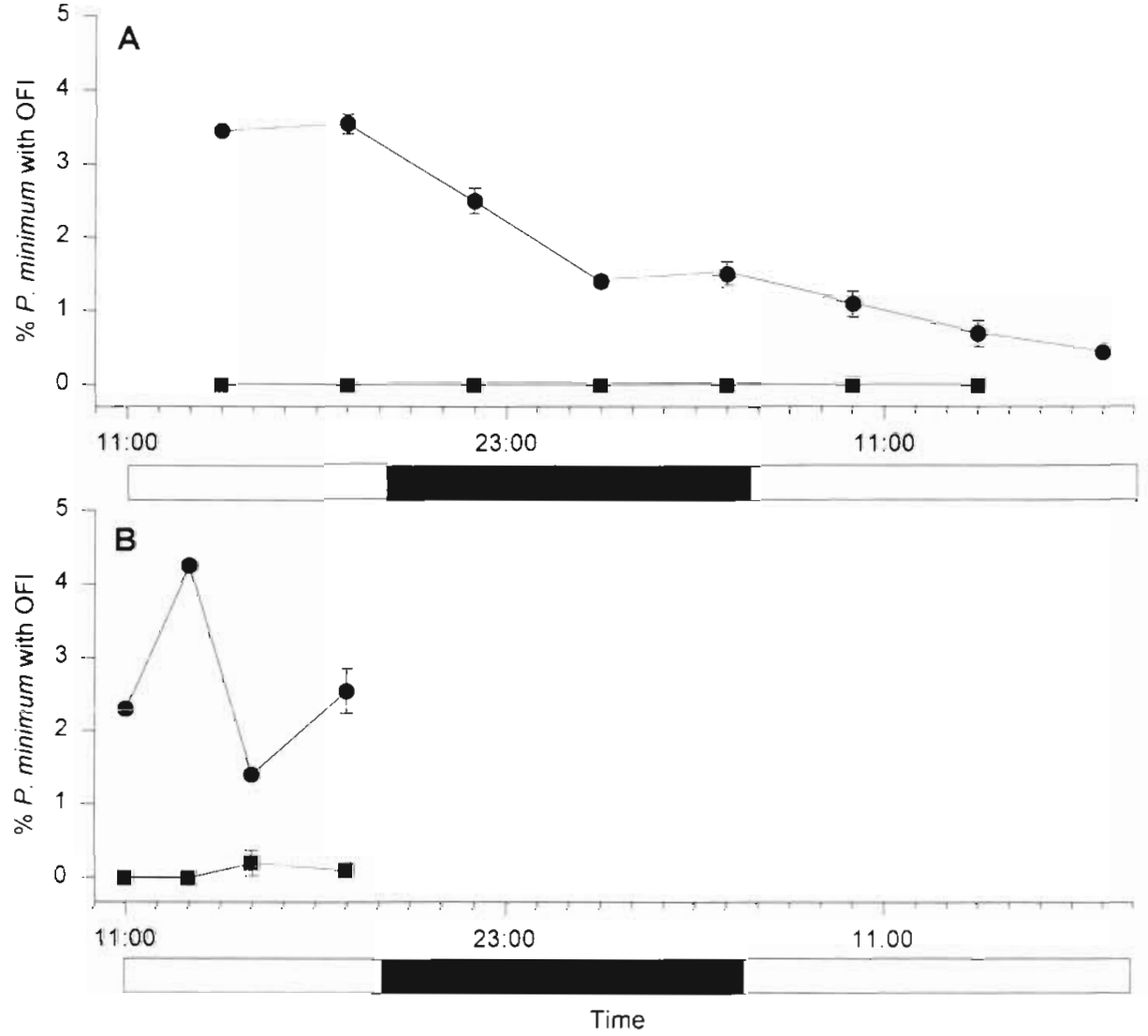

Time
Fig. 8. Prorocentrum minimum. Effect of inorganic nutrients and incubation time on feeding by cultures on Cryptomonas sp. in on-deck experiments. Black bar indicates interval between sunset and sunrise. Feeding is indicated by presence of orange fluorescent inclusions (OFI). Means \pm SE. (A) Comparison of OFI in cultures that had been grown in complete $\mathrm{f} / 2$-Si medium ( $\boldsymbol{\square}$ ) and medium lacking added nitrate and phosphate (TM medium) (O). (B) Effect of addition of nltrate $(883 \mu \mathrm{M})$ and phosphate $(36 \mu \mathrm{M})$ on feeding of $P$. minimum grown in TM medium. (a) Treatment with nutrients added $24 \mathrm{~h}$ prior to feeding trials; (-) control treatment
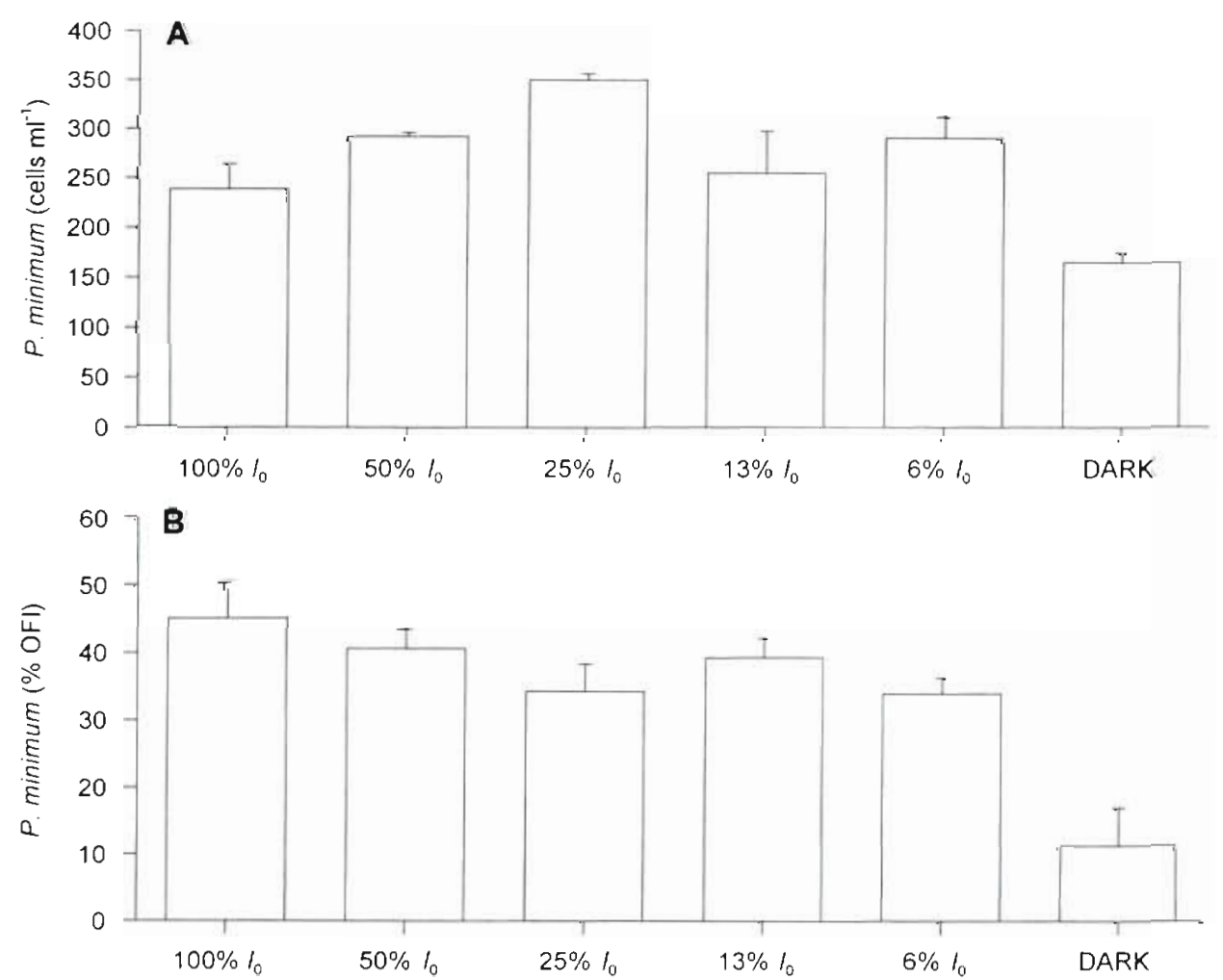

Fig. 9. Prorocentrum minimum. Effect of light on abundance and feeding of cells from natural assemblages; 7 July 1996 ondeck experiment. Presence of orange fluorescent inclusions (OFI) indicates feeding. Mean \pm SE 
with cultures, feeding was observed in treatments without added nutrients (Fig. 8), but the incidence of feeding was low (<5\%) compared with some (Figs. 5, 6 \& 9), but not all (Fig. 7, control) experiments with natural assemblages. The low percent feeding in culture may be due to the presence of some stored nitrogen or phosphorus in cells at stationary phase or perhaps due to selection against the propensity to eat by culture conditions.

The response to nutrients was complex. In experiments with natural assemblages, addition of phosphate or nitrate alone and low level nutrient additions sometimes appeared to stimulate feeding, indicating that perhaps intracellular nitrogen and phosphate ratios are important. In Chesapeake Bay, phytoplankton growth appears to be limited by dissolved inorganic phosphorus during spring and by dissolved inorganic nitrogen in summer (Malone et al. 1996); thus, depending on the time of year, the response to additions may differ. In many dinoflagellates, nitrogen uptake is strongly tied to photosynthesis. However, in Prorocentrum minimum light and dark rates of nitrate assimilation are similar (Paasche et al. 1984) and this species is able to maintain constant growth rates when inorganic nitrogen is supplied in pulses every day or two (Sciandra 1991). This apparent ability to store nitrogen may be partially responsible for the time delays observed between changes in nutrient availibility and induction or inhibition of feeding and the differences in response between experiments.

Another important factor is the diel cycle, which has a pronounced influence on feeding by Prorocentrum minimum (Figs. $5 \& 6$ ). Although prolonged ( $24 \mathrm{~h}$ ) exposure to dark inhibits feeding, in a natural diel cycle, ingestion usually peaks around midnight and then declines in the early morning. In dinoflagellates, complex circadian rhythms interact with the light:dark cycle and nutrient supply in regulating both physiological functions and cell division (Olson \& Chisholm 1983, Sweeney \& Folli 1984, Roenneberg 1996). One possible explanation for the observed temporal pattern in feeding is that photosynthesis during the first half of the light period creates an anabolic demand for nitrogen and phosphorus. Under nutrient-limiting conditions, feeding may be induced by the afternoon and may continue until nutrient quotas for cell division are met.

Feeding may be an important aspect of the ecology of many bloom-forming dinoflagellates. Dinoflagellate blooms often develop and persist in surface waters where nutrient concentrations are low (Paasche et al. 1984). It has been hypothesized that dinoflagellates can continue to grow under low nutrient conditions by obtaining nitrogen during evening migrations into nutrient-rich subsurface waters (Harrison 1976). Ingestion may be an alternative mechanism by which dinofla- gellates supplement their nutrient requirements in the late afternoon and evening. As in bacterivorous phytoflagellates (Thingstad et al. 1996), feeding may affect the outcome of competition among species for nutrients.

Similar feeding patterns may be found in other dinoflagellates and may contribute to their ability to form persistent blooms. In Chesapeake Bay, 4 other bloomforming photosynthetic dinoflagellates, Gymnodinium sanguineum, Gyrodinium uncatenum, Ceratium furca and Gyrodinium estuariale also prey on other protists (Bockstahler \& Coats 1993a, b, Li et al. 1996). Food vacuoles have been reported in other photosynthetic dinoflagellates including Alexandrium ostenfeldii, Gonyaulax diegensis, Scrippsiella sp., Ceratium longipes, Prorocentrum micans and Fragilidium subglobosum (Jacobson \& Anderson 1996. Skovgaard 1996). Feeding may be common among photosynthetic dinoflagellates under growth-limiting conditions and may contribute to their ability to dominate their competitors and to form blooms that persist after nutrients are depleted in surface waters.

Acknowledgements. We thank the Captain and crew of the RV 'Cape Henlopen' for ship operation and on-deck assistance and E. J. Adam for technical assistance at sea. This research was supported by NSF grant OCE931772 awarded to D.W.C. and D.K.S. and a Maryland Sea Grant college REU student internship awarded to M.K.N. CEES contribution no. 2836

\section{LITERATURE CITED}

Bockstahler KR, Coats DW (1993a) Grazing of the mixotrophic dinoflagellate Gymnodinium sanguineum on ciliate populations of Chespeake Bay. Mar Biol 116:477-487

Bockstahler KR, Coats DW (1993b) Spatial and temporal aspects of mixotrophy in Chesapeake Bay dinoflagellates. J Euk Microbiol 40:49-60

Caron DA, Sanders RW, Lim EL, Marrase C, Amaral LA, Whitney S, Aoki RB, Porter KG (1993) Light-dependent phagotrophy in the freshwater mixotrophic chrysophyte Dinobryon cylindricum. Microb Ecol 25:93-111

Faust MA (1974) Micromorphology of a small dinoflagellate Prorocentrum mariae-lebouriae (Parke \& Ballantine) comb. nov. J Phycol 10:315-322

Grzebyk D. Berland B (1996) Influences of temperature, salinity and irradiance on growth of Prorocentrum minimum (Dinophyceae) from the Mediterranean Sea. J Plankton Res 18:1837-1849

Guillard RRL (1975) Culture of phytoplankton for feeding marine invertebrates. In: Smith WL, Chanley MH (eds) Culture of marine invertebrate animals. Plenum Publishing Corp, New York, p 29-60

Harding LW Jr (1988) The time course of photoadaptation to low light in Prorocentrum mariae-lebouriae (Dinophyceae). J Phycol 24:274-281

Harding LW Jr, Coats DW (1988) Photosynthetic physiology of Prorocentrum mariae-lebouriae (Dinophyceae) during its subpycnocline transport in Chesapeake Bay. J Phycol $24: 77-89$ 
Harrison WG (1976) Nitrate metabolism of the red tide dinoflagellate Gonyaulax polyedra Stein. J Exp Mar Biol Ecol 21:199-209

Ishida Y, Kimura B (1986) Photosynthetic phagotrophy of Chrysophyceae: evolutionary aspects. Microbiol Sci 3: $132-135$

Jacobson DM, Anderson DM (1996) Widespread phagocytosis of ciliates and other protists by marine mixotrophic and heterotrophic thecate dinoflagellates. J Phycol 32:279-285

Jones HLJ, Leadbeater BSC. Green JC (1993) Mixotrophy in marine species of Chrysochromulina (Prymnesiophyceae): ingestion and digestion of a small green flagellate. J Mar Biol Assoc UK 73:283-296

Li A, Stoecker DK, Coats DW, Adam EJ (1996) Ingestion of fluorescently labeled and phycoerythrin-containing prey by mixotrophic dinoflagellates. Aquat Microb Ecol 10 : $139-147$

Malone TC, Conley DJ, Fisher TR, Glibert PM, Harding LW, Sellner KG (1996) Scales of nutrient-limited phytoplankton productivity in Chesapeake Bay. Estuaries 19 $371-385$

Nygaard K, Tobiesen A (1993) Bacterivory in algae: a survival siraleyy during nutrient iimitation. Limnol Oceanogr 38. $273-279$

Olson RJ, Chisholm SW (1983) Effects of photocycles and periodic ammonium supply on three marine phytoplankton species. I. Cell division patterns. J Phycol 19:522-528

Paasche E, Bryceson I, Tangen K (1984) Interspecific variation in dark nitrogen uptake by dinoflagellates. J Phycol 20: $394-401$

This article was submitted to the editor
Roenneberg T (1996) The complex circadian system of Gonyaulax polyedra. Physiol Plant 96:733-737

Sanders RW (1991) Mixotrophic protists in marine and fresh water ecosystems. J Protozool 38:76-81

Schnepf E, Elbrächter $M(1992)$ Nutritional strategies in dinoflagellates - a review with emphasis on cell biological aspects. Eur J Protistol 28:3-24

Schnepf E, Winter S (1990) A microtubular basket in the armoured dinoflagellate Prorocentrum micans (Dinophyceae). Arch Protistenkd 138:89-91

Sciandra A (1991) Coupling and uncoupling between nitrate uptake and growth rate in Prorocentrum minimum (Dinophyceae) under different frequencies of pulsed nitrate supply. Mar Ecol Prog Ser 72:261-269

Skovgaard A (1996) Mixotrophy in Fragilidium subglobosum (Dinophyceae): growth and grazing responses as functions of light intensity. Mar Ecol Prog Ser 143:247-253

Sweeney BM. Folli SI (1984) Nitrate deficiency shortens the circadian period in Gonyaulax. Plant Physiol 75: 242-245

Thingstad TF, Havskum H, Garde K, Riemann B (1996) On the strategy of 'eating your competitor': a mathematical analysis of algal mixotrophy. Ecology 77:2108-2118

Tyler MA. Seliger HH (1978) Annual subsurface transport of a red tide dinoflagellate to its bloom area: water circulation patterns and organism distributions in the Chesapeake Bay. Limnol Oceanogr 23:227-246

Tyler MA, Seliger HH (1981) Selection for a red tide organism: physiological responses to the physical environment. Limnol Oceanogr 26:310-324

Manuscript first received: January 15, 1997

Revised version accepted: April 7, 1997 